\title{
Anti-oxidative and cytotoxic attributes of phenolic rich ethanol extract of Musa balbisiana Colla inflorescence
}

\author{
Vageesh Revadigar ${ }^{1}$, Majed Ahmed Al-Mansoub ${ }^{1}$, Muhammad Asif ${ }^{2}$, Mohammad Razak Hamdan ${ }^{3}$, \\ Amin Malik Shah Abdul Majid ${ }^{2}$, Mohd Zaini Asmawi ${ }^{1}$, Vikneswaran Murugaiyah ${ }^{1 *}$ \\ ${ }^{1}$ Discipline of Pharmacology, School of Pharmaceutical Sciences, Universiti Sains Malaysia, 11800Penang, Malaysia. \\ ${ }^{2}$ EMAN Testing and Research Laboratory, School of Pharmaceutical Sciences, Universiti Sains Malaysia, 11800, Penang, Malaysia. \\ ${ }^{3}$ Centre for Drug Research, Universiti Sains Malaysia, 11800, Penang, Malaysia.
}

\section{ARTICLE INFO}

Article history:

Received on: 09/04/2016

Accepted on: 16/09/2016

Available online: 30/05/2017

Key words:

Musa balbisiana Colla, antioxidant, cytotoxicity, morphological changes, apoptosis.

\begin{abstract}
Inflorescence of Musa species is one of the most commonly consumed vegetables in Southeast Asian region. In the present study, chemical composition and antioxidant potential of the ethanolic extract of inflorescence of Musa balbisiana Colla (MbCi) were evaluated. In addition, the extract was also subjected to cytotoxicity testing on a panel of human cancer cell lines. The ethanolic extract of inflorescence of Musa balbisiana Colla was evaluated for antioxidant activity using 1,1-diphenyl-2-picryl-hydrazyl assay (DPPH), 2,2'-azino-bis (3ethylbenzothiazoline-6-sulphonic acid) (ABTS) and ferric reducing antioxidant power (FRAP) assays. The extract was chemically characterized for total phenolic (TPC) and total flavonoid (TFC) contents and by gas chromatography-mass spectrometry (GC-MS) analysis. Cytotoxicity was evaluated by MTT cell viability assay. The extract showed moderate antioxidant activity in all the antioxidant assays. Chemically, the extract was found to possess high total phenolic $(92.01 \pm 0.40 \mu \mathrm{g}$ gallic acid equivalent/mg extract) but low flavonoid (4.852 $\pm 0.04 \mu \mathrm{g}$ quercetin equiv./mg extract) contents. In cell viability assay, $\mathrm{MbCi}$ extract showed selective cytotoxicity towards HT-29 cell line. Morphological observations show that MbCi has apoptosis inducing nature. GC-MS analysis has revealed the presence of 22 compounds, mainly belonging to steroids, fatty acids and long chain aliphatic compounds, which in part may be responsible for observed antioxidant and cytotoxic activities of ethanol extract. Our study revealed that MbCi has chemotherapeutic potential activity that warrants further investigation.
\end{abstract}

\section{INTRODUCTION}

Plants from genus Musa contribute as the fourth most important food in the world today. Musa species are natives to Indo-Malaysian, Asian and Australian tropics (Nelson et al., 2006). Inflorescence of Musa species (banana) is much appreciated vegetable in Malaysia. The inner part of inflorescence as well as lower soft inner part of pseudostem is widely used for cooking (Vimala et al., 2003). Decoction of half ripe fruit of Musa balbisiana Colla (MbC) is used in the

\footnotetext{
* Corresponding Author

Discipline of Pharmacology, School of Pharmaceutical Sciences, Universiti Sains Malaysia, 11800 Penang, Malaysia.

Email:vicky@ usm.my
}

treatment of dysentery. In India, exudates from rhizomatous stem of $\mathrm{MbC}$ are used for the treatment of pinworm infection (Kalita and Deb, 2004), while the tablets prepared from the fresh and dried seed paste of MbC are used as contraceptives (Das et al., 2014). Decoction from the pith of Musa species is used in the treatment of congestive heart failure and hypertension by Temuan tribe of Peninsular Malaysia (Azliza et al., 2012). Musa species are studied extensively for their pharmacological activities. Kumar et al. (2012), reported that flavonoid leucocyanidin significantly increase the thickness of the mucous membrane layer of the stomach and improved gastric ulcer in comparison with antacid. Aqueous extract from the roots of $\mathrm{MbC}$ produced significant size reduction in albumin induced hind paw edema in Wistar rats in a dose dependent manner (Ibegbu et al., 2012). 
Fresh dried pulp of the fruit was reported to possess in vitro as well in vivo antioxidant activity in a dose dependent manner (Mudoi et al., 2011). Antioxidant activity of eight Malaysian bananas were reported by Sulaiman et al. (2011), who found that the chloroform extract of dried pulp possessed good antioxidant activity. The authors also reported weak correlation between the antioxidant activity and total phenolic content of the samples. Vilela et al. (2014) identified GC-MS of dichloromethane extracts of several Musa species and reported the presence of lipophilic phytochemicals. Hitherto, there is no data available on the antioxidant activity and cytotoxicity of inflorescence of Musa balbisiana Colla (MbCi). Therefore, the present study was designed to investigate the phytochemical composition, antioxidant capacity and cytotoxicity of $\mathrm{MbCi}$.

\section{MATERIALS AND METHODS}

\section{Plant materials}

Inflorescence of $\mathrm{MbC}$ was collected from Balik Pulau hilly area, Penang, Malaysia. A voucher specimen (11559) was deposited in Herbarium Unit at the School of Biological Sciences, Universiti Sains Malaysia.

\section{Preparation of $\mathrm{MbCi}$ extract}

The fresh inflorescences were cut into smaller pieces, crushed and triturated in mortar and pestle by addition of small amount of ethanol and made into paste. This mass was further extracted by maceration for 6 days with absolute ethanol. The extracts were filtered using whatman filter paper and concentrated using rotavapor (Heidolph Instruments; Schwabach, Germany). Then, the extracts were stored in sealed vial at $4{ }^{\circ} \mathrm{C}$ until biological testing. All determinations were done in triplicate and absorbencies were measured using microplate reader (TECAN Infinite Pro® M200, Switzerland).

\section{Chemical characterization Total phenolic content}

Total phenolic content was determined using FolinCiocalteu reagent following the method described by Kumaran and Joel Karunakaran (2007), using gallic acid as a reference standard. The assay was carried out by mixing Folin-Ciocalteu reagent, sodium carbonate, standard/extract sample and distilled water in a test tube in a ratio of $5: 15: 1: 79$ to the final volume of $1000 \mu \mathrm{L}$. The tubes were incubated for 2 hour at room temperature and an aliquot $(200 \mu \mathrm{L})$ of each mixture was transferred into 96-well microplate. The amount of test sample was substituted by distilled water in blank. Absorbencies were taken at $765 \mathrm{~nm}$. The results are expressed as $\mu \mathrm{g}$ gallic acid equivalent/mg dry extract.

\section{Total flavonoid content}

Total flavonoid content was determined by the aluminum chloride method as described by Orhan et al. (2011) using quercetin as a reference standard. For the assay, the standard or extract solutions $(100 \mu \mathrm{L})$ were mixed with of $10 \%(\mathrm{w} / \mathrm{v})$ aluminum chloride $(20 \mu \mathrm{L}), 1 \mathrm{~mol} / \mathrm{L}$ sodium acetate $(20 \mu \mathrm{L})$ methanol $(300 \mu \mathrm{L})$ and distilled water $(560 \mu \mathrm{L})$. After incubation at room temperature for $30 \mathrm{~min}$, the absorbance of the reaction mixture was measured at $415 \mathrm{~nm}$. The results are expressed as $\mu \mathrm{g}$ quercetin equivalent/mg dry extract.

\section{Gas Chromatography Mass Spectrometry (GC-MS) analysis}

The chemical composition of $\mathrm{MbCi}$ was determined using Agilent GC-MS system consisting of a gas chromatograph (Agilent 6890) coupled to a mass spectrophotometer (Agilent 5973; inert mass selective detector). Separation was achieved on a HP-5 MS column of $30 \mathrm{~m}$ length, $0.25 \mathrm{~mm}$ diameter consist of film thickness $0.25 \mu \mathrm{m}$. The injector was set at $70{ }^{\circ} \mathrm{C}$ for 2 minutes and steadily increased $20^{\circ} \mathrm{C}$ up to $285^{\circ} \mathrm{C}$. Helium was used as the carrier gas with the flow rate of $20 \mathrm{~mL}$ per minute. An amount of 2 $\mu \mathrm{L}$ of sample was injected. Transfer line was maintained at 250 ${ }^{\circ} \mathrm{C}$. The mass spectrophotometer was operated at $1717.6 \mathrm{eV}$. The total run time was 47.75 minutes. The identification of compounds was done by using NIST 02 library.

\section{Antioxidant assays \\ DPPH scavenging assay}

Free radical scavenging activity was determined using 2,2-Diphenyl-2-Picrylhydrazyl (DPPH) as described by AlMansoub et al. (2014). A $100 \mu \mathrm{L}$ of the extract sample $(0.78-$ 200) $\mu \mathrm{g} / \mathrm{mL}$ dissolved in DMSO were mixed with $100 \mu \mathrm{L}$ of DPPH $(200 \mu \mathrm{mol} / \mathrm{L})$ dissolved in methanol, and the reaction mixture was incubated at room temperature for $30 \mathrm{~min}$. Ascorbic acid was used as a reference standard. The absorbance was measured at $517 \mathrm{~nm}$. The results are expressed as $\mathrm{IC}_{50}$.

\section{ABTS radical scavenging activity assay}

ABTS radical scavenging activity was measured by themodified ABTS cation decolorization assay as described by Al-Mansoub et al. (2014) as described by Re et al. (1999). ABTS radical cation $\left(\mathrm{ABTS}^{\circ+}\right)$ solution was prepared by mixing of 14 $\mathrm{mM}$ ABTS and $4.9 \mathrm{mM}$ potassium persulfate $\left(\mathrm{K}_{2} \mathrm{~S}_{2} \mathrm{O}_{8}\right)$ dissolved in deionized water in equal volumes. This solution was allowed to react in the dark place at room temperature for 16-20 $\mathrm{h}$ before use. Then, $1 \mathrm{~mL}$ of stock $\mathrm{ABTS}^{\circ+}$ solution was then diluted with $40 \mathrm{~mL}$ of deionized water to yield an absorbance equals to $0.70 \pm 0.02$ at $734 \mathrm{~nm}$. In Brief, to $180 \mu \mathrm{L}$ of ABTS radical solution, $20 \mu \mathrm{l}$ of sample extract $(3.13-400) \mu \mathrm{g} / \mathrm{mL}$ were added. Ascorbic acid was used as a reference standard. The absorbance of $\mathrm{ABTS}^{\circ+}$ sample extract/standard was taken at $734 \mathrm{~nm}$. The results are expressed as $\mathrm{IC}_{50}$.

\section{Ferric reducing antioxidant power (FRAP) assay}

The FRAP assay was carried out by method of Benzie and Strain (1996) as developed by Griffin and Bhagooli (2004). FRAP working solution was prepared by mixing $(300 \mathrm{mmol} / \mathrm{L})$ acetate buffer, $\mathrm{pH} 3.6(10 \mathrm{mmol} / \mathrm{L}) \mathrm{TPTZ}$ in $(40 \mathrm{mmol} / \mathrm{L}) \mathrm{HCl}$ and (20 mmol/L) $\mathrm{FeCl}_{3}$ in a ratio of 10:1:1. An amount of $150 \mu \mathrm{L}$ of 
working solution was added to $50 \mu \mathrm{L}$ standard/extracts. Blank was done in the same way using methanol instead of test solutions. The reaction mixture was incubated for $8 \mathrm{~min}$ then readings were taken at $600 \mathrm{~nm}$. Ferrous sulfate $\left(\mathrm{FeSO}_{4} \cdot 7 \mathrm{H}_{2} \mathrm{O}\right)$ was used as reference standard and the results are expressed as nmol $\mathrm{Fe}^{+2}$ equivalent $/ \mathrm{mg}$ dry extract.

\section{In vitro anticancer assays Cell viability assay}

Cytotoxicity of MbCi was tested on EA.hy926 (human normal endothelial cells) and four cancer cell lines namely, MCF-7 (human breast cancer ATCC ${ }^{\circledR}$ HTB-22), HeLa (human cervical carcinoma ATCC $^{\circledR}$ CCL-2), HT-29 (human colorectal adenocarcinoma ATCC $^{\circledR}$ HTB-38) and HCT 116 (human colorectal carcinoma ATCC ${ }^{\circledR}$ CCL-247) using MTT assay [3-(4,5dimethylthiazol-2-yl)2,5-diphenyl tetrazolium bromide] following the protocol described by Asif et al. (2016). MCF7 and HeLa cells were cultured in Dulbecco's Modified Eagle medium (DMEM) (Gibco ${ }^{\circledR}$ Invitrogen) whereas HT-29 and HCT-116 were cultured in Roswell Park Memorial Institute medium (RPMI) (Gibco ${ }^{\circledR}$ Invitrogen) supplemented with fetal bovine serum (10\%) and penicillin-streptomycin (1\%) (Gibco ${ }^{\circledR}$ Invitrogen). Cells were maintained at $37{ }^{\circ} \mathrm{C}$ in a water saturated atmosphere containing 5\% $\mathrm{CO}_{2}$. Counting of cells was done using a Neubauer hemocytometer under light microscope by using trypan blue (Gibco ${ }^{\circledR}$ Invitrogen) staining method. Cells of 5,000 to 10,000 densities per well seeded in a 96 well plate and treated with different concentrations (100$3.125 \mu \mathrm{g} / \mathrm{mL})$ of ethanolic extract dissolved in DMSO $(0.5 \%$ in final concentration). 5-fluorouracil (5-FU) was used as the reference standard and $0.5 \%$ DMSO was used as the negative control. The treated cells were incubated for 48 hours. The absorbance was read using microplate reader (TECAN infinite Pro ${ }^{\circledR}$ M200, Switzerland) at $570 \mathrm{~nm}$ using 620 as reference wavelength. The results were presented as percent viability.

\section{Morphological analysis}

Changes in the morphology of cells treatred with $\mathrm{MbCi}$ were studied following well established method of Ebrahim et al. (2014) with some modifications. In brief, overnight seeded cells $\left(5 \times 10^{5}\right)$ were incubated with $\mathrm{IC}_{50}$ vlaues of MbCi for 48 hours in a 6-well tissue culture plate. At the end of treatment period, the medium was discarded and cells were washed once with PBS. The changes in the morphology of treated cells were observed using inverted phase contrast microscope at $10 \times$ magnification.

\section{Statistical analysis}

Data are presented as mean \pm standard error of mean (SEM). The minimum inhibitory concentration $\left(\mathrm{IC}_{50}\right)$ was calculated from the linear regression equations of dose response curve for each experiment. All statistics analyses were carried out using SPSS software (20.0 version).

\section{RESULTS}

\section{Chemical characterization of ethanol extract}

The extract was chemically characterized by colorimetric and GC-MS methods.

\section{Total phenolic and flavonoid contents}

$\mathrm{MbCi}$ was revealed to have higher total phenolic content $(92.02 \pm 0.40 \mu \mathrm{g}$ gallic acid equiv./mg extract) and low total flavonoid content $(4.85 \pm 0.05 \mu \mathrm{g}$ quercetin equiv./mg extract) (Table 1).

\section{GC-MS analysis}

The GC-MS analysis has shown the presence of 22 compounds in the extract; among these 16 compounds were found to be with more than $90 \%$ of similarity with NIST 02 library. These identified compounds belong to the class of steroids, long chain unsaturated and saturated hydrocarbons, esters and fatty acids.

On the other hand, compounds with less similarity index while found to be in major proportion could be predicted as the polyphenolics by considering the higher TPC value of the extract. The extract was enriched with major sterols stigmasterol, betasitosterol, and campesterol, in descending order of abundance. However, the quantitative analysis of the tested extract revealed that the major dominant peak corresponds to Z-12-Pentacosene $(8.23 \%)$, followed by stigmasterol $(7.33 \%), 10$-Heneicosene $(5.73 \%)$, and beta-sitosterol (5.23\%) (Table 2, Figure 1).

\section{Antioxidant Assays}

Finding of the present study shows that $\mathrm{MbCi}$ has moderate antioxidant activity in DPPH, ABTS free radical scavenging, while ferric reducing antioxidant power of the $\mathrm{MbCi}$ in FRAP assay demonstrated good activity.

The antioxidant results of $\mathrm{MbCi}$ in these respective assays are shown in Table 1.

The DPPH and ABTS $\mathrm{IC}_{50}$ values of $\mathrm{MbCi}\left(\mathrm{IC}_{50}\right.$ value is the concentration of the sample required to inhibit $50 \%$ of radical) were $64.24 \pm 3.09$ and $76.23 \pm 2.20 \mu \mathrm{g} / \mathrm{mL}$. The results were compared to reference standard ascorbic acid which were found to be $5.41 \pm 0.41 \mu \mathrm{g} / \mathrm{mL}$ and $3.49 \pm 0.05 \mu \mathrm{g} / \mathrm{mL}$, for the DPPH and ABTS assays, respectively. In addition, the $\mathrm{MbCi}$ showed good antioxidant activity in FRAP test with a value of $70.08 \pm 12.86$ nmol $\mathrm{Fe}^{+2}$ equiv./mg extract.

Table 1: Antioxidant activity of ethanolic extract of Musa balbisiana Colla inflorescence.

\begin{tabular}{|c|c|c|c|c|c|}
\hline Sample & $\begin{array}{c}\text { Total phenolic } \\
\text { ( } \mu \text { g gallic acid } \\
\text { equiv./mg extract) }\end{array}$ & $\begin{array}{c}\text { Total flavonoid } \\
\text { ( } \mu \text { g quercetin } \\
\text { equiv./mg extract) }\end{array}$ & $\begin{array}{c}\text { DPPH } \\
\text { IC }_{50}(\mu \mathrm{g} / \mathrm{mL})\end{array}$ & $\begin{array}{c}\text { ABTS } \\
\text { IC }_{50}(\mu \mathrm{g} / \mathrm{mL})\end{array}$ & 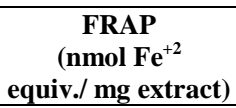 \\
\hline MbCi & $92.02 \pm 0.40$ & $4.85 \pm 0.05$ & $64.24 \pm 3.09$ & $76.23 \pm 2.20$ & $70.08 \pm 12.86$ \\
\hline Vitamin C (Standard) & - & - & $5.41 \pm 0.41$ & $3.49 \pm 0.05$ & - \\
\hline
\end{tabular}

Values are expressed as mean \pm SEM $(n=3)$. 
Table 2: GC-MS profile of ethanolic extract of Musa balbisiana Colla inflorescence

\begin{tabular}{|c|c|c|c|c|c|c|}
\hline S. No. & Compound & $\begin{array}{l}\text { Retention } \\
\text { time }\end{array}$ & Area \% & Molecular formula & Molecular weight & Similarity index \\
\hline 1 & Hexadecanoic acid, methyl ester & 10.37 & 3.89 & $\mathrm{C}_{17} \mathrm{H}_{34} \mathrm{O}_{2}$ & 270.450 & 99 \\
\hline 2 & 9,12- octadecanoic acid (z,z)-methyl ester & 11.13 & 3.02 & $\mathrm{C}_{19} \mathrm{H}_{34} \mathrm{O}_{2}$ & 294.472 & 99 \\
\hline 3 & Heptadecanoic acid, 16-methyl-, methyl ester & 11.21 & 1.47 & $\mathrm{C}_{19} \mathrm{H}_{38} \mathrm{O}_{2}$ & 298.503 & 94 \\
\hline 4 & Linoleic acid ethyl ester & 11.40 & 0.79 & $\mathrm{C}_{20} \mathrm{H}_{34} \mathrm{O}_{2}$ & 308.498 & 99 \\
\hline 5 & 9-Tricosene, (Z)- & 11.74 & 0.74 & $\mathrm{C}_{23} \mathrm{H}_{46}$ & 322.611 & 99 \\
\hline 6 & Heptadecane & 11.83 & 0.64 & $\mathrm{C}_{17} \mathrm{H}_{36}$ & 240.468 & 96 \\
\hline 7 & 10-Heneicosene & 12.51 & 5.73 & $\mathrm{C}_{20} \mathrm{H}_{34}$ & 310.600 & 99 \\
\hline 8 & Hexadecane,2,6,10,14-tetramethyl- & 12.60 & 3.67 & $\mathrm{C}_{20} \mathrm{H}_{42}$ & 282.547 & 96 \\
\hline 9 & Z-12-Pentacosene & 13.31 & 8.23 & $\mathrm{C}_{25} \mathrm{H}_{50}$ & 350.665 & 91 \\
\hline 10 & Eicosane & 13.40 & 0.49 & $\mathrm{C}_{20} \mathrm{H}_{42}$ & 282.547 & 92 \\
\hline 11 & 1-Nonadecene & 14.29 & 4.21 & $\mathrm{C}_{19} \mathrm{H}_{38}$ & 266.505 & 95 \\
\hline 12 & 17-Pentatriacontene & 15.63 & 2.45 & $\mathrm{C}_{35} \mathrm{H}_{70}$ & 490.930 & 93 \\
\hline 13 & Vitamin E & 16.53 & 1.98 & $\mathrm{C}_{29} \mathrm{H}_{50} \mathrm{O}_{2}$ & 430.706 & 98 \\
\hline 14 & Campesterol & 17.80 & 2.79 & $\mathrm{C}_{28} \mathrm{H}_{48} \mathrm{O}$ & 400.680 & 99 \\
\hline 15 & Stigmasterol & 18.15 & 7.33 & $\mathrm{C}_{29} \mathrm{H}_{48} \mathrm{O}$ & 412.691 & 91 \\
\hline 16 & Beta-sitosterol & 18.92 & 5.23 & $\mathrm{C}_{29} \mathrm{H}_{50} \mathrm{O}$ & 414.706 & 99 \\
\hline
\end{tabular}

Compounds having similarity index with NIST02 library more than 90 were considered for reporting

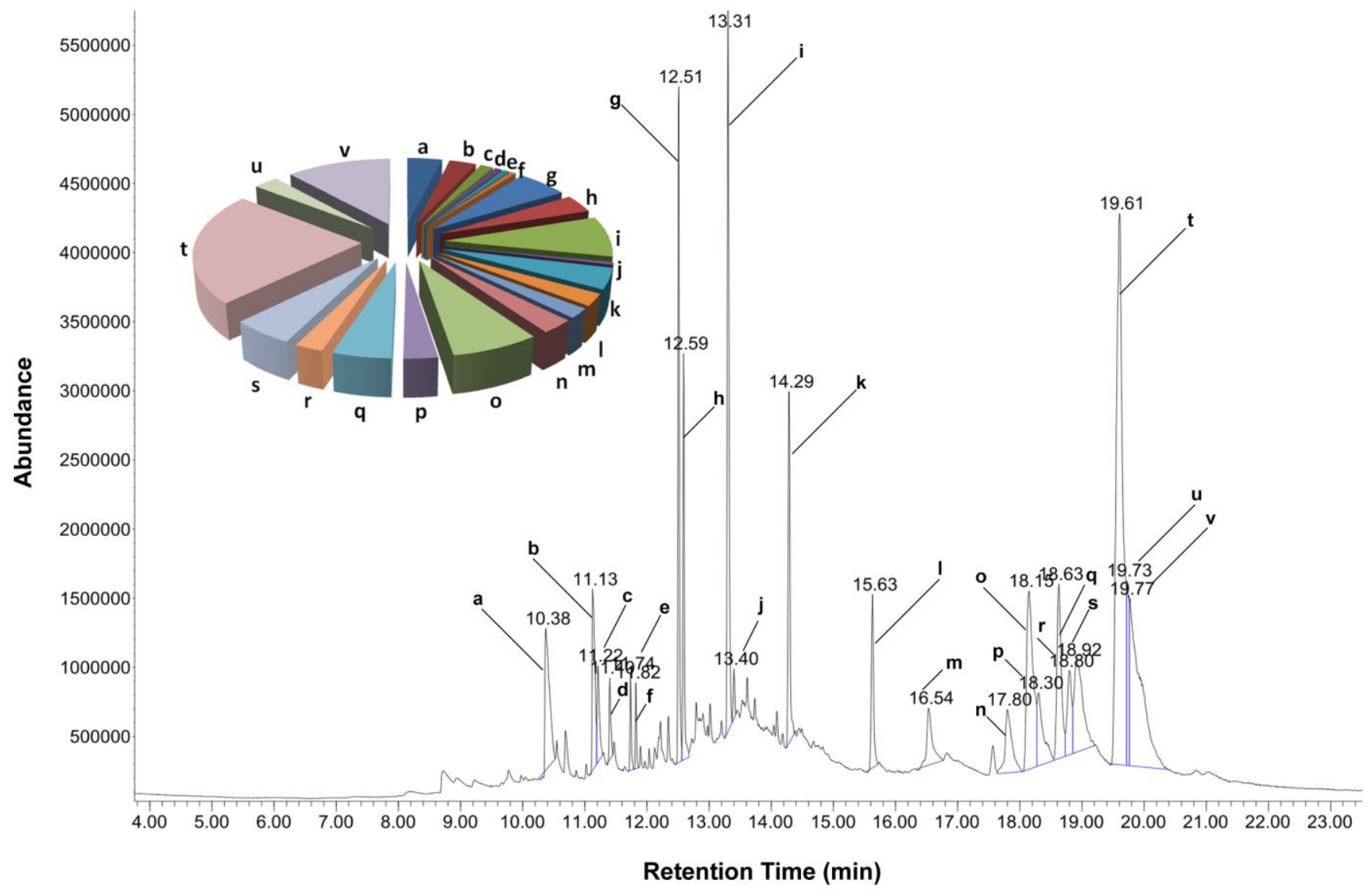

Fig. 1: Gas chromatography-mass spectrometry (GC-MS) chromatogram, and the pie chart depicts the percentage of each phytochemical present in the ethanolic extract of Musa balbisiana Colla inflorescence. The identification of compounds was done by using NIST 02 library. Where, $\mathrm{i}=\mathrm{Z}-12$-Pentacosene $(8.23 \%)$, $\mathrm{o}=$ stigmasterol (7.33\%), $\mathrm{g}=10$-Heneicosene $(5.73 \%)$, and $\mathrm{s}=$ beta-sitosterol $(5.23 \%)$. 
Table 3: Cytotoxicity of ethanolic extract of Musa balbisiana Colla inflorescence against panel of cell lines

\begin{tabular}{cc}
\hline Cell lines & $\mathbf{I C}_{\mathbf{5 0}}(\boldsymbol{\mu \mathbf { g }} / \mathbf{m L})$ \\
\hline MCF-7 Breast cancer & $61.81 \pm 0.64$ \\
HCT 116 Colon cancer & $39.89 \pm 1.63$ \\
HT-29 Colon cancer & $5.25 \pm 0.26$ \\
HeLa Cervical cancer & $114.08 \pm 6.12$ \\
EA.hy926 Normal human endothelial & $66.64 \pm 3.56$
\end{tabular}

Values are expressed as mean \pm SEM $(n=3)$.

HT-29
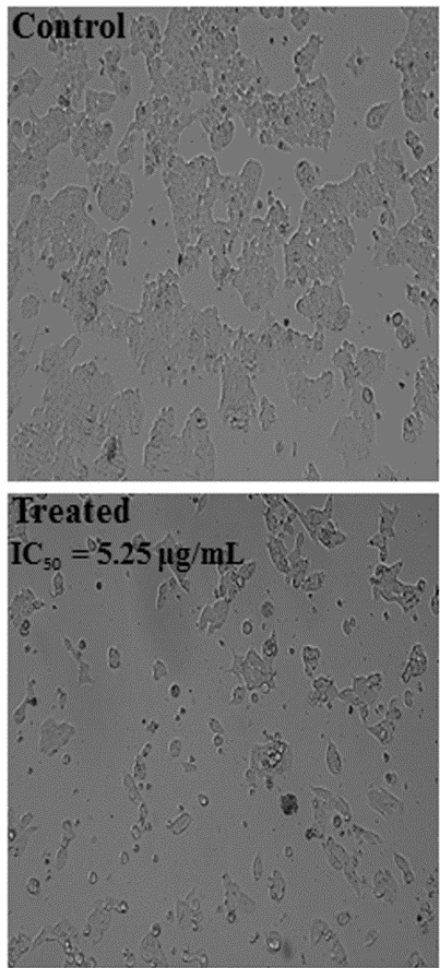

HCT 116
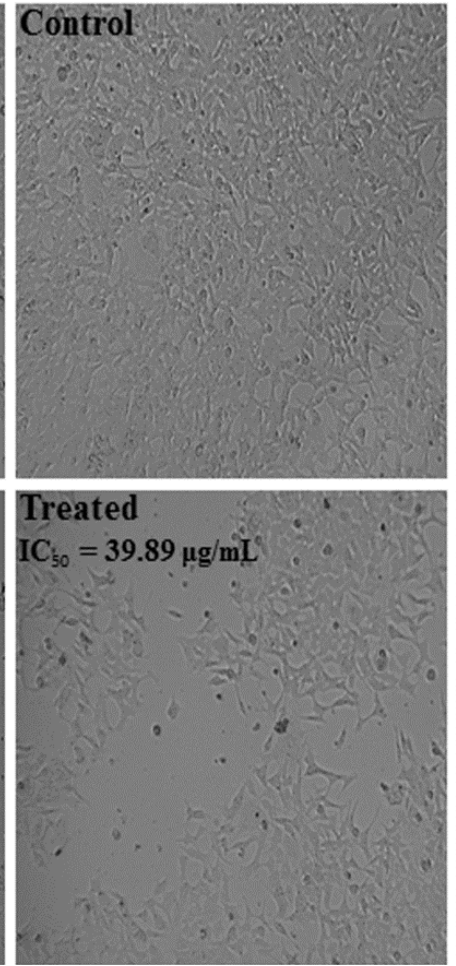

MCF-7

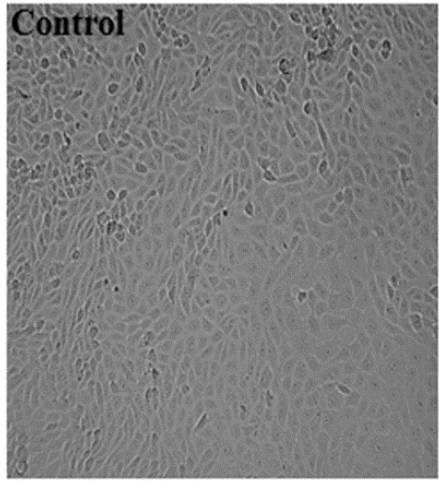

\section{Treated}

$\mathrm{IC}_{\mathrm{so}}=61.81 \mu \mathrm{g} / \mathrm{mL}$
HeLa
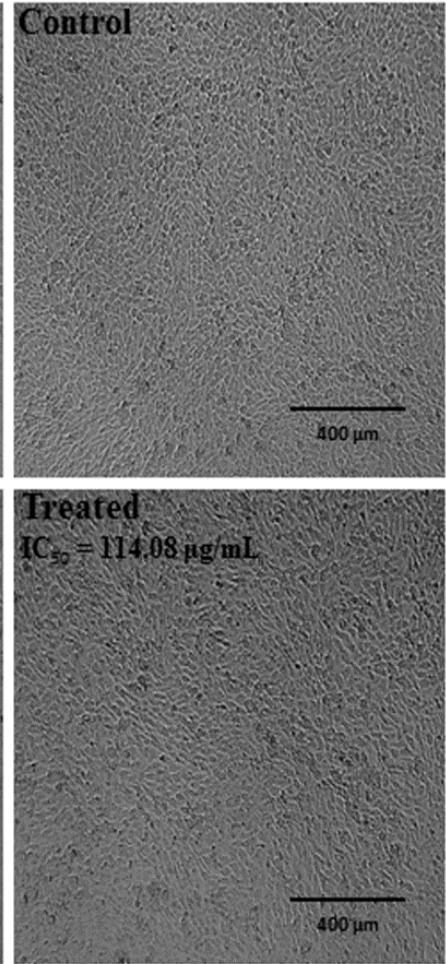

Fig. 2: Cytotoxicity of ethanolic extract of Musa balbisiana Colla inflorescence towards a panel of human cancer cell lines after $48 \mathrm{~h}$ of treatment. Photos were taken at $10 \times$ magnification (scale bar $400 \mu \mathrm{m}$ ).
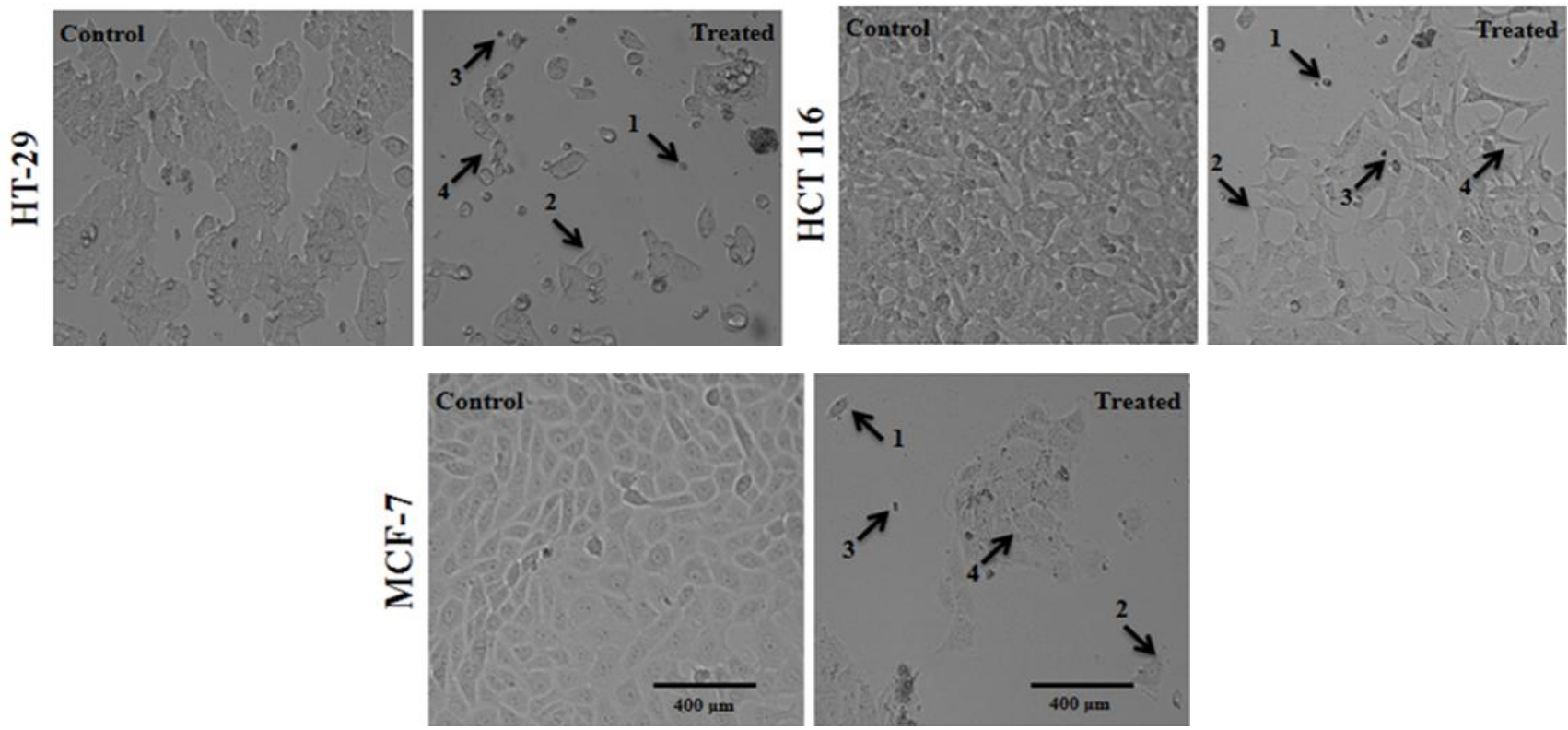

Fig. 3: The morphological changes observed in human cancer cell lines treated with ethanolic extract of Musa balbisiana Colla inflorescence. Where $1=$ cell shrinkage, $2=$ membrane blebbing, $3=$ dead cells and $4=$ loss contact with neighboring cells. Photos were taken at $10 \times$ magnification (scale bar $400 \mu \mathrm{m}$ ). 


\section{In vitro anticancer assays Cell viability assay}

The extract showed selective cytotoxicity on two colorectal cancer cell lines, namely HT-29 and HCT 116. Meanwhile moderate cytotoxicity was found on MCF-7 human breast cancer cell line and the extract was found relatively nontoxic on HeLa cells (Table 3, Figure 2). Treatment of MbCi for 48 $\mathrm{h}$ exhibited no cytotoxic activity towards normal human endothelial cells (EA.hy926) with $\mathrm{IC}_{50}$ of $66.64 \pm 3.56 \mu \mathrm{g} / \mathrm{mL}$.

\section{Morphological analysis}

Monitoring of $\mathrm{MbCi}$ extract treated cells under phase contrast microscope after $48 \mathrm{~h}$ showed significant morphological changes compared to control cells (0.5\% DMSO). The $\mathrm{MbCi}$ induced typical apoptotic changes in the morphology of all HCT 116, HT-29 and MCF-7 cells. Figure 3 highlights the morphological changes induced in human cancer cell lines as a result of exposure to the extract of $\mathrm{MbCi}(10 \times$ magnification).

\section{DISCUSSION}

Development of cancer involves three main phases namely, initiation, promotion and progression phases. The currently employed treatment strategy which mainly includes radiation, chemotherapy, immunosuppression and surgery have limited prospective as indicated by high morbidity and mortality rate. Thus, there is a need for new treatment strategies towards the treatment of cancer. Chemoprevention is one such major strategy which involves use of pharmacological, dietary biofactors, phytochemicals and even whole plant extracts to prevent, arrest or reverse the cellular and molecular processes of carcinogenesis. Several recent studies have proven that various dietary phytochemicals are significantly effective in controlling, inhibiting the carcinogenesis. Research has also effectively proven that total plant extract possess significant effect over single compound mainly because of synergistic effects of cocktail of various metabolites and multiple points of intervention in chemoprevention. These phytochemicals found to act through different mechanisms such as inhibition of genotoxic effects, increased antioxidant and anti-inflammatory activity, inhibition of proteases and cell proliferation, protection of intercellular communications to modulation of apoptosis and signal transduction pathways (Shafi Sofi et al., 2013). With this background and based on previous literature availble on dietary sources, Musa balbisiana Colla was not only used as food source but also possess traditional uses as anticancer agents. The ethanolic extract from infloroscences of Musa balbisiana Colla was selected for its antioxidant and anticancer activity on various major cell lines in our current study.

In the present study, ethanol extract of Musa balbisiana infloroscences was tested against a panel of human of cancer cell lines. Finding of study shows that ethanol extract was selectively active towards human colorectal carcinoma HT-29 cell line. The order of selectivity was HT-29> HCT $116>\mathrm{MCF}-7>\mathrm{HeLa}$ respectively. In addition, the $\mathrm{MbCi}$ has no cytotoxic activity towards normal human endothelial cells (EA.hy926). Morphological observations reveal that ethanol extract of $\mathrm{MbCi}$ induced typical apoptotic changes i.e., cell shrinkage, membrane blebbing and loosening of contact with each other. Finding of our study are in line with other research reports where similar type of apoptotic changes was induced in cancer cells as a result of exposure to natural product (Shafi et al., 2008).

It is a fact that a single assay cannot represent the behaviour of free radicals and antioxidants in a living system. Therefore, we performed an array of assays in the present study (i.e. DPPH, ABTS and FRAP models) to investigate the oxidant scavenging potential of ethnaol extract. Our findings indicated good antioxidant activity of $\mathrm{MbCi}$ in the FRAP model, and moderate activity in the DPPH and ABTS models, respectively. These assays could provide a more precise description of antioxidant activity, which indicates that the pharmacological effects of MbCi might be due to multiple antioxidant mechanisms.

In an attempt to establish a link between the antioxidant effects of $\mathrm{MbCi}$ and their polyphenolic contents, we further estimated the phenolic and flavonoid contents of $\mathrm{MbCi}$ by adopting common methods reported in the literature. Several lines of evidences suggest that phenolics act as good free radical scavengers and capable of reducing the oxidative stress. Therefore, phenolics act not only as antioxidants but also have beneficial effect as anticancer agents (Surh et al., 2008; Yang et al., 2008). Polyphenolic compounds are abundant in plants and may associated to provide protection against several chronic diseases (Ovaskainen et al., 2008).

Epidemiological studies revealed that high dietary intake of polyphenols is linked with decreased risk of a range of diseases including cardiovascular disease and some forms of cancer $(\mathrm{Hu}$, 2011). Plant-derived phenolic compounds such as phenolic acids, flavonoids, quinones, coumarins, lignans, stilbenes and tannins have shown promising results in different antioxidant and anticancer models (Huang et al., 2009). The phenolic compounds is mainly attributed to their redox properties and may either act as an efficient radical scavengers, ion chelators, such as iron and copper (Bilušić Vundać et al., 2007), or may exert the anticancer effects and inhibit cancer cell growth through a variety of mechanisms (Vauzour et al., 2010).

Detailed chemical characterization by GC-MS revelas that $\mathrm{MbCi}$ also contains steroidal compounds. Compounds with steroidal pharmacophore are reported to possess cytotoxicity through several mechanisms (Gupta et al., 2013). On the other hand, phytosterols are triterpenes and important structural components of plant membranes (Moreau et al., 2002). It was demonstrated that the most common dietary are $\beta$-sitosterol, campesterol and stigmasterol may offer protection from the colon, breast and prostate cancer (Awad et al., 2000). Moreover, early studies reported that $\beta$-sitosterol inhibits the growth of HT-29 human colon cancer cells and alters membrane lipids by activating the sphingomyelin cycle (Awad et al., 1996; Awad et al., 1998). Woyengo et al. (2009) reported that the phytosterols seem 
to act through several mechanisms of action, including inhibition of carcinogen production, cancer-cell growth, angiogenesis, invasion and metastasis, and through the promotion of apoptosis of cancerous cells. Phytosterols including $\beta$-sitosterol, stigmasterol and campesterol detected in the MbCi extract exhibited the most abundant sterol compounds in the diet. It has been established that diet significantly impacts one's risk for cancer disease (Grattan, 2013). Previous studies have been reported that triterpene steroid stigmasterol compound has a moderate radical scavenger activity. In addition, the stigmasterol was the most potent as an anticancer agent towards WiDr cells lines (Sahidin et al., 2014; Sahidin et al., 2015).

The results of our phytochemical analysis reveal that the cytotoxicity of the extract is mainly due to the synergistic effect of class of secondary metabolites, which present in high content of polyphenols and compounds with steroidal nucleus. The ethanolic extract of $\mathrm{MbCi}$ has also shown the presence of minor amount of fatty acids, long chain saturated and unsaturated hydrocarbons. Studies have revealed that polyunsaturated fatty acids and their metabolites are capable of inducing apoptosis, cell cycle arrest, capable of attenuating cyclooxygenase enzyme (COX) levels and also act as free radical scavengers in cancer cell lines ( $\mathrm{Xu}$ et al., 2014).

\section{CONCLUSION}

In conclusion, the findings of the present study suggest that the ethanolic extract of inflorescence of Musa balbisiana Colla possess moderate antioxidant activity and promising cytotoxicity on HT-29 and HCT-116 colorectal human cancer cell lines, while moderate cytotoxicity on MCF-7 breast cancer cell line. The MbCi extract has no cytotoxicity on HeLa cervical cancer on normal human endothelial (EA.hy926) cell lines. This activity may be due to its high total phenolic and steroidal contents. Thus, further investigations to isolate pure compounds for its potential anticancer mechanisms are warranted.

\section{ACKNOWLEDGEMENT}

The authors would like to express their gratitude to the Institute of Post Graduate Studies (IPS), Universiti Sains Malaysia for providing the financial support and research facilities.

\section{Financial support and sponsorship: Nil.}

Conflict of Interests: There are no conflicts of interest.

\section{REFERENCES}

Al-Mansoub MA, Asmawi MZ, Murugaiyah V. Effect of extraction solvents and plant parts used on the antihyperlipidemic and antioxidant effects of Garcinia atroviridis: a comparative study. J Sci Food Agr, 2014; 94(8): 1552-1558.

Asif M, Yehya AHS, Al-Mansoub MA, Revadigar V, Ezzat MO, Khadeer Ahamed MB, Oon CE, Murugaiyah V, Abdul Majid AS, Abdul Majid AMS. Anticancer attributes of Illicium verum essential oils against colon cancer. S Afr J Bot, 2016; 103: 156-161.
Awad A, Chen Y, Fink C, Hennessey T. beta-Sitosterol inhibits HT-29 human colon cancer cell growth and alters membrane lipids. Anticancer Res, 1996; 16(5A): 2797-2804.

Awad A, Von Holtz R, Cone J, Fink C, Chen Y. beta-Sitosterol inhibits growth of HT-29 human colon cancer cells by activating the sphingomyelin cycle. Anticancer Res, 1998; 18(1A): 471-473.

Awad AB, Fink CS. Phytosterols as Anticancer Dietary Components: Evidence and Mechanism of Action. The J Nutr, 2000; 130(9): 2127-2130.

Azliza MA, Ong HC, Vikineswary S, Noorlidah A, Haron NW. Ethno-medicinal resources used by the Temuan in Ulu Kuang Village. Ethno Med, 2012; 6(1): 17-22.

Benzie IFF, Strain JJ. The Ferric Reducing Ability of Plasma (FRAP) as a Measure of "Antioxidant Power": The FRAP Assay. Anal Biochem, 1996; 239(1): 70-76.

Bilušić Vundać V, Brantner AH, Plazibat M. Content of polyphenolic constituents and antioxidant activity of some Stachys taxa. Food Chem, 2007; 104(3): 1277-1281.

Das B, Talukdar A, Choudhury MD. A few traditional medicinal plants used as antifertility agents by ethnic people of Tripura, India. Int J Pharm Pharm Sci, 2014; 6(1): 47-53.

Ebrahim K, Shirazi FH, Vatanpour H, zare A, Kobarfard F, Rabiei H. Anticancer Activity of Cobra Venom Polypeptide, Cytotoxin-II, against Human Breast Adenocarcinoma Cell Line (MCF-7) via the Induction of Apoptosis. J Breast Cancer, 2014; 17(4): 314-322.

Grattan BJ. Plant Sterols as Anticancer Nutrients: Evidence for Their Role in Breast Cancer. Nutrients, 2013; 5(2): 359-387.

Griffin SP, Bhagooli R. Measuring antioxidant potential in corals using the FRAP assay. J Exp Mar Biol Ecol, 2004; 302(2): 201211.

Gupta A, Sathish Kumar B, Negi AS. Current status on development of steroids as anticancer agents. J Steroid Biochem Mol Biol, 2013; 137: 242-270.

Hu M-L. Dietary polyphenols as antioxidants and anticancer agents: more questions than answers. Chang Gung Med J, 2011; 34(5): $449-460$

Huang W-Y, Cai Y-Z, Zhang Y. Natural Phenolic Compounds From Medicinal Herbs and Dietary Plants: Potential Use for Cancer Prevention. Nutr Cancer, 2009; 62(1): 1-20.

Ibegbu AO, Okonji UJ, Hamman WO, Umana UE, Ikyembe DT, Musa SA. Anti-inflammatory effects of the aqueous Extracts of plantain roots (Musa Species). Br J Clin Pharmacol Toxicol, 2012; 3(2): 70-75.

Kalita D, Deb B. Some folk medicines used by the Sonowal Kacharis tribe of the Brahmaputra valley, Assam. Nat Prod Radiance, 2004; 3(4): 240-246.

Kumar KPS, Bhowmik D, Duraivel S, Umadevi M. Traditional and medicinal uses of banana. J Pharmacogn Phytochem, 2012; 1(3): 5163.

Kumaran A, Joel Karunakaran R. In vitro antioxidant activities of methanol extracts of five Phyllanthus species from India. LWT - Food Sci Technol, 2007; 40: 344-352.

Moreau RA, Whitaker BD, Hicks KB. Phytosterols, phytostanols, and their conjugates in foods: structural diversity, quantitative analysis, and health-promoting uses. Prog Lipid Res, 2002; 41(6): 457-500.

Mudoi T, Deka DC, Tamuli S, Devi R. Fresh ripe pulp (FRP) of Musa balbisiana fruit has antiperoxidative and antioxidant properties: an in vitro and in vivo experimental study. J Pharm Res, 2011; 4(11): 42084213.

Nelson SC, Ploetz RC, Kepler AK. 2006. Musa species (banana and plantain), ver. 2.2. In: Elevitch, C.R. (ed.). Species Profiles for Pacific Island Agro forestry. Permanent Agriculture Resources (PAR), Hōlualoa, Hawai'i. Available at: http://www.traditionaltree.org [Accessed 25 June 2016].

Orhan N, Orhan IE, Ergun F. Insights into cholinesterase inhibitory and antioxidant activities of five Juniperus species. Food Chem Toxicol, 2011; 49(9): 2305-2312. 
Ovaskainen M-L, Törrönen R, Koponen JM, Sinkko H, Hellström J, Reinivuo H, Mattila P. Dietary Intake and Major Food Sources of Polyphenols in Finnish Adults. J Nutr, 2008; 138(3): 562-566.

Re R, Pellegrini N, Proteggente A, Pannala A, Yang M, RiceEvans C. Antioxidant activity applying an improved abts radical cation decolorization assay. Free Rad Biol Med, 1999; 26: 1231-1237.

Sahidin I, Nohong, Sani A, Anggrenimanggau M, Sukohar A, Widodo H, Baharum S. Radical scavenging activity of triterpene steroids from stem of polygonum pulchrum BL. Int J Pharm Pharm Sci, 2014; 6(8): 350-354.

Sahidin I, Suwandi A, Nohong, Manggau MA. Profile of anticancer and radical scavenging activities of steroids from stems of Polygonum pulchrum. IJPSR, 2015; 6(5): 2178-2184.

Shafi G, Hasan TN, Syed NA. Methanolic Extract of Nigella sativa Seeds is Potent Clonogenic Inhibitor of PC3 Cells. Int J Pharm, 2008; 4(6): 477-481.

Shafi Sofi M, Sateesh MK, Bashir M, Harish G, Lakshmeesha TR, Vedashree S, Vedamurthy AB. Cytotoxic and pro-apoptotic effects of Abrus precatorius L. on human metastatic breast cancer cell line, MDAMB-231. Cytotechnology, 2013; 65(3): 407-417.

Sulaiman SF, Yusoff NAM, Eldeen IM, Seow EM, Sajak AAB, Supriatno, Ooi KL (). Correlation between total phenolic and mineral contents with antioxidant activity of eight Malaysian bananas (Musa sp.). J Food Comp Anal, 2011; 24(1): 1-10.

Surh Y-J, Kundu JK, Na H-K. Nrf2 as a Master Redox Switch in Turning on the Cellular Signaling Involved in the Induction of Cytoprotective Genes by Some Chemopreventive Phytochemicals. Planta Med, 2008; 74(13): 1526-1539.
Vauzour D, Rodriguez-Mateos A, Corona G, Oruna-Concha MJ, Spencer JPE. Polyphenols and Human Health: Prevention of Disease and Mechanisms of Action. Nutrients, 2010; 2(11): 1106-1131.

Vilela C, Santos SAO, Villaverde JJ, Oliveira L, Nunes A, Cordeiro N, Freire CSR, Silvestre AJD. Lipophilic phytochemicals from banana fruits of several Musa species. Food Chem, 2014; 162: 247-252.

Vimala S, Adenan MI, Ahmad AR, Shahdan R. Nature's Choice to Wellness: Antioxidant Vegetables/Ulam, (Vol. 7). Kepong, Kuala Lumpur: Forest Research Institute of Malaysia, 2003; 69-71.

Woyengo TA, Ramprasath VR, Jones PJH. Anticancer effects of phytosterols. Eur J Clin Nutr, 2009; 63(7): 813-820.

$\mathrm{Xu}$ Y, Qian SY. Anti-cancer activities of $\omega-6$ polyunsaturated fatty acids. Biomed J, 2014; 37(3): 112-119.

Yang CS, Ju J, Lu G, Xiao H, Hao X, Sang S, Lambert JD. Cancer prevention by tea and tea polyphenols. Asia Pac J Clin Nutr, 2008; 17(Suppl 1): 245-248.

\section{How to cite this article:}

Revadigar V, Al-Mansoub MA, Asif M, Hamdan MR, AbdulMajid AMS, Asmawi MZ, Murugaiyah V. Anti-oxidative and cytotoxic attributes of phenolic rich ethanol extract of Musa balbisiana Colla inflorescence. J App Pharm Sci, 2017; 7 (05): 103-110. 